\title{
DEVELOPMENT OF TEACHING MATERIALS FOR SASAK ALUS LANGUAGE AS CULTURAL PRESERVATION AND LEARNING RESOURCES
}

\author{
Zul Anwar $^{1}$, Basuki Wibawa ${ }^{2 *}$, Nurdin Ibrahim ${ }^{3}$ \\ ${ }^{1,2,3}$ Education Technology Studies Program, State University of Jakarta, Indonesia. \\ Email: ${ }^{1 *}$ bwibawa@unj.ac.id, ${ }^{2}$ zulanwarr@gmail.com, ${ }^{3}$ nurdin1349@yahoo.com \\ Article History: Received on $30^{\text {th }}$ August 2019, Revised on $30^{\text {th }}$ September 2019, Published on $14^{\text {th }}$ October 2019
}

\begin{abstract}
Purpose: This study aims to develop language teaching materials as a learning resource for fourth-grade students in elementary school.

Methodology: The approach used in this study is library research that is operationalized by the development method. The procedure of development research according to Gall and Borg consists of ten steps, namely; (1) research and information collecting), (2) planning, (3) developing preliminary form of product), (4) preliminary field testing, (5) main product revision, (6) main field testing, (7) operational product revision, (8) operational field testing, (9) final product revision, (10) dissemination and implementation.

Main Findings: The results showed that the instructional materials developed were suitable to be used as learning resources with the results of content expert validation $84.5 \%$, media expert validation $77.2 \%$, instructional design expert validation $83.2 \%$. The results of trials one to one by learner $80.8 \%, 85.4 \%$ small group, and $85.8 \%$ field trial.

Implications: Based on the results of the test it was concluded that the teaching materials developed were suitable to be used as learning resources. The products of this study can be used to apply the concept of resource-based learning and improve the quality of local subject learning in the Sasak Alus language in elementary school.
\end{abstract}

Keywords: Development, Teaching Material, Learning Resources, Sasak Alus Language, Instructional materials.

\section{INTRODUCTION}

Some research results show that Sasak Alus language has a strategic role that can be used as an alternative solution in resolving horizontal conflicts that often occur in the Sasak community (Mugni, 2012). The value of politeness and mutual respect as the basic principle of harmony can be formed through the practice of communication using Sasak Alus language (Hidayat, 2010). The language revitalization through local subject learning in formal schools is absolutely necessary to instill since the basic principles of harmony, peace, and harmonization to students. According to Prastiwi (2013), local subject learning has a strategic role as a means of preserving local culture, customs, and regional languages to foster the spirit of unity in diversity. The active role of regional government is needed to survive the culture of the local area, (Kumalasari, 2019).

In addition, the results of other studies also show that local wisdom in the form of culture can also be used as a rationale for developing a social interaction in the community that adheres to the values of local wisdom (Suryadi \& Kusnendi, 2016). The development of the character of the Indonesian people through local culture is needed by transforming local cultural values as one of the means to build the character of the nation (Yunus, 2013) This shows that local wisdom in the form of culture and language in the community can be used as a philosophy of life for the people who adhere to that culture. Besides being able to be used as a means to shape the character of the community based on the noble values of local communities, culture is also the identity of a particular community group which can be used as a study of science, giving birth to a branch of knowledge about intercultural communication (Sumiati, 2017).

On the other hand, the existence of globalization has given an impression and impact on the shift in perspective and the lifestyle of the people of Lombok. Where culture and local wisdom are considered and identified as something out of date and old-fashioned especially by today's young generation. The onslaught of globalization into the Lombok community is a threat to indigenous cultures that portray the locality typical of regions in Indonesia (Mubah, 2011). The existing multicultural diversity in the form of regional languages, ethnic customs, ordinances, arts, crafts, regional skills, etc. is a characteristic that enriches the values of Indonesian life. Therefore this diversity must always be preserved, developed, and maintained through the local subject of education (Andrian, Kartowagiran, \& Hadi, 2018).

The holding of local content subjects is based on the fact that in Indonesia there are various regional languages, cultures, and customs that each region is different. Through lessons of the local subject, diversity is passed on to the next generation. The school is given the authority to develop its own local subject curriculum to provide students with broad insight into the specificities that exist in their environment (Bjork, 2004).

Based on the details and results of the research conducted by the experts mentioned above, the revitalization of Sasak Alus language is absolutely necessary. Through the revitalization and learning of Sasak Alus language in school, there will be a growing attitude of politeness, politeness, respect for others, disposing of ego attitude, group fanaticism, and increasing respect for others in students. For the purpose of revitalization through learning, it is necessary to prepare learning 
resources that can support the smooth learning process. The learning process can occur well when there is the availability of learning resources (Sitepu B. 2014). Development and provision of various learning resources that are in accordance with the conditions of the target, the style and learning patterns of students need to be developed to improve the quality of the learning process.

\section{LITERATURE REVIEW}

In general, learning resources can be divided into two namely learning resources by design and by utilization (Januszewski \& Molenda, 2008). The development of learning resources is intended to facilitate students in learning. Learning resources can be specifically designed for learning purposes so students are independently able to identify the learning resources needed to achieve their learning goals (Wong, 2012).

To achieve the learning objectives, students can utilize a variety of learning resources that are available in an integrated manner by utilizing various learning resources that are around and learning resources developed (Chen \& Huang, 2012). At present, digital learning resources such as social media are increasingly being used as learning environments and learning resources (Manca \& Ranieri, 2013). The availability of learning resources greatly determines the quality of learning and the achievement of learning objectives (Poon, 2013). In addition to the types of learning resources mentioned above, (Bruff, et al., 2013) said that online digital video learning resources specifically designed and provided as learning resources can be used for learning and training. In line with the results of Derek's research, Scanlon, et al. also said that the availability of online digital learning resources that can be accessed freely has an impact on the learning model that provides opportunities for students to life-long learning (Scanlon, et al., 2015). The availability of learning resources that can be accessed freely digitally as now has produced various types and ways of learning. With these various learning resources students have the opportunity to study anytime and anywhere to improve their abilities by constructing their own knowledge (Amry 2014). Learning resources function to improve the process of studying and learning (Hadjerrouit, 2010) Based on the opinions of the experts above, it can be understood that learning resources are an important factor so that the learning process will occur in students.

Learning is a conscious effort that is carried out in a planned, systematic manner, and uses certain methods to change relatively settled behavior through interaction with learning resources. Thus, learning resources are one component in learning activities that allow individuals to gain knowledge, abilities, attitudes, beliefs, emotions, and feelings. The source of learning is something that can be used to support and facilitate the learning process. According to Percival and Ellington as quoted by Sitepu said that learning resources used in education and training are a system consisting of a set of materials or situations that are created intentionally and made so as to enable students to learn individually. This learning source is called media education or instructional media (Sitepu, 2014).

The teaching and learning process is a system that is inseparable from the interrelated components in it. One of these components is a learning resource. The source of learning is everything that can be in the form of subject matter, video, books, audio, CBT, programs, and various learning packages combined with media (Dorrell, 1993). Sources of learning can also be interpreted with all the resources that are utilized for the benefit of teaching and learning both directly and indirectly, in part or as a whole. Miarso said that learning can be carried out anywhere, at school, at home, at work, in places of worship, and in the wider community (various systems). In addition, learning can also be done with internal and external stimuli, namely from within oneself or from what and who is outside of themselves (Miarso, 2005). Further explained, that learning resources are all things in the form of objects and people who can support learning activities. Learning resources can be divided into two categories, namely: (a) learning resources (resources for learning) and (b) learning resources as learning places (resources as learning), namely materials or tools used to facilitate learning activities.

The understanding of learning resources that have been discussed in the previous section spark several distribution types of learning resources. Learning resources can be divided into the following: (1) background: the surrounding natural environment, that is, wherever people can do learning or behavior change processes then that place can be categorized as a place of learning that means or as a learning resource, such as libraries, markets, museums, rivers, mountains, landfills, fish ponds, and so on. In addition to the real environment, the social media-based learning environment can also be said to be a learning resource that is currently widely used as the object of research by researchers today such as research conducted by (Hsu \& Hwang, 2017). The results of the study show that web-based learning resources are a way for teachers to engage students in the learning process in the classroom (Mohammadi, et al., 2015). (2) Message: information conveyed by other components, usually in the form of ideas, meanings, and facts. In the context of learning, this message is related to the contents of the field of study and will be managed and reconstructed by the learner. Learning messages are not only sourced from certain learning sources but can also be transmitted by learners so learning is reciprocal. The results of other studies also show that learning using various methods and approaches combined with utilizing HP (mobile learning) as a learning resource proves that it influences student learning outcomes.(3) People, that is, anyone who has certain skills in which learners can learn something, then the person concerned can be categorized as a learning resource. For example: teachers, geologists, soldiers, community leaders, and other experts. (4) Material: this group is often referred to as software. Material functions to store messages before being distributed using a tool that has been designed. Materials are everything in the form of written, printed, electronic, web, and other text that can be used for learning. Such learning resources such as; maps, globe, films (non tv), graphics, images, diagrams, and so on. (5) Tools: this type is often called hardware. The tool is used to issue messages stored in the material. Tools are physical objects that are often referred to as 
hardware, which serve to present learning materials. Tools that are all objects that allow changes in behavior for students, so that objects can be categorized as learning resources, such as; LCD, OHP, camera, television radio, VCD and so on. (6) Practice: standard procedures or guidelines for the steps in delivering messages. In other words, techniques are ways or procedures that people use in providing learning to achieve learning goals. Learning resources in the form of techniques that can be utilized for learning are lectures, varied lectures, discussions, programmed learning, individual learning, group learning, simulations, games, exploration studies, field studies, questions and answers, assignments and the like. Including events and facts, that are happening, such as riots, catastrophic events, and other events that the teacher can make events or facts as a source of learning (Seels \& Richey, 1994). Many digital-based learning sources are studied today which are termed technological learning environments (

Kemp classifies learning resources by using learning and teaching approaches in large and small classes and with learning that is appropriate for the speed of individual students. The choice of learning resources according to him is based on the characteristics of the learning objectives to be achieved and the characteristics of the contents of the field of study that they want to learn. Besides other factors such as whether or not the media is available and whether or not the teacher can use it. Actually there are variables that influence the selection of learning delivery strategies, namely the characteristics of the field of study and the availability of learning resources. The characteristics of the field of study need to be a special consideration when determining the choice of learning media that will be used to deliver learning. In general, learning resources can be classified into; human learning resources, print-based learning resources, visual-based learning resources, audio-visual based learning resources, and computer-based learning resources. Based on the classification of learning resources, in this study, a learning resource for the type of print was developed in the form of teaching material books to support the learning process of the local subject of Sasak Alus language. This type of learning source was developed based on the results of the analysis of the needs and conditions of the target users.

Learning resources have a very important role not only in the process of learning but also in everyday life. According to (Katz, 2003) says that there are two functions of learning resources, namely to entertain and convey information. For existing learning resources to function in learning is possible to be used as well. Whereas Smellie and Kemp (1989) say that the function of learning resources is to: (1) improve learning productivity by (a) accelerating the pace of learning and helping learners to use time better and (b) reducing the burden of learning/teachers in presenting information, so that they can foster more and develop student learning motivation. (2) Providing the possibility of learning that is more individual in nature, by (a) reducing rigid and traditional teaching controls; and (b) provide opportunities for learners to develop according to their abilities. (3) providing a more scientific basis for learning by (a) designing a more systematic learning program, and (b) the developing of learning materials based on research. (4) Strengthening learning, with a way to (a) improve the ability of learning resources; (b) more concrete information and material presentation. (5) Enabling instant learning, namely: (a) reducing the gap between verbal and abstract learning with concrete or reality; (b) providing direct knowledge. (6) Allowing the presence of broader learning, by presenting information that is able to penetrate geographical boundaries.

The use of learning resources in the learning and teaching process will produce a pattern of student interaction with learning resources. The interaction patterns according to Supriadi (2015) are as follows: (1) traditional passive; is the pattern of interaction of students with learning resources, namely teachers only, where teaching staff is used as the only source of learning, there is no effort for students to find other learning resources outside the teacher, (2) traditionally active; is the pattern of student interaction with learning resources, where students make teachers as the main learning source, but there have been efforts to find other learning resources partially to complement the material obtained from the teacher, (3) patterns of interaction in various directions; is the pattern of interaction between students with a variety of learning resources, where students make use of various learning resources in the learning process, and (4) independent interactions; is a pattern of interaction between learners and learning resources where learners actively interact independently with the source of the trunk without the control of the teaching staff to complete the messages obtained from the teacher/instructor. Interaction and communication between teachers and students can help students to improve their learning performance and motivation.

Based on the definition of the above definition, it can be concluded that learning resources as a source of inspiration and knowledge can be anything that can be used for learning purposes. The availability of learning resources is closely related to improving the quality of learning, so there is an assumption that the more available and quality the availability of learning resources, the better the quality of learning where the learning resources are utilized to the fullest.

\section{METHODOLOGY}

\section{Method}

The approach used in this study is an approach to the library research paradigm (library research) that is operationalized by the development method. The procedure of development research according to Gall and Borg consists of ten steps, namely; (1) research and information collecting), (2) planning, (3) developing preliminary form of product), (4) preliminary field testing, (5) main product revision, (6) main field testing, (7) operational product revision, (8) operational field testing, (9) final product revision, (10) dissemination and implementation. 


\section{Procedure}

The steps of the research and development model basically have four main steps; (i) needs analysis, (ii) product development, (iii) product validation and evaluation, and (iv) implementation and dissemination. The following is a description of the four steps: (1) needs analysis. At this stage, the main activity carried out was to analyze the problem of the need to develop a source for the learning of Sasak Alus language. Analysis of language learning needs was carried out using a learning needs questionnaire adapted from Jack C. Richards (Richards, 2003). In addition to using questionnaires, interviews were also conducted with teachers, principals, and the community to get information about the need to learn Sasak Alus language. The results of the needs analysis are used as a reference for the next step. (2) Development. At this stage, a conceptual framework is developed for development steps which are then used as a reference for the realization of the product development draft. (3) Validate and Evaluate. To ensure that the products of development are suitable to be used, an evaluation is conducted through expert validation tests (one to one evaluation by experts) and student trials (one to one evaluation by learners), small group evaluations, and field trials (field trial). Evaluations were carried out by experts and students using questionnaires adapted from the book Evaluation and Selection of Learning Resources: A Guide (Department of Education, 2008). The assessment range is 1-4 with the interpretation of the 4 categories that are very feasible, the value of 3 categories is feasible, the value of 2 categories is not feasible, the value of 1 category is not feasible. In the questionnaire a special column is provided to fill suggestions, criticisms, and input on the learning resources developed.(4) Implementation. At this stage applied the learning source products as a result of the development also carried out the test of the effectiveness of the product of the development results by comparing the conditions or learning outcomes before and after the product was developed.

\section{Subject and object}

The location of this study is in Central Lombok Regency, West Nusa Tenggara Province, Indonesia. The research objects were elementary school students. The selection of respondents for preliminary research was carried out purposively (consideration), namely schools that applied Sasak Alus language as part of local subject learning material. Respondents were also taken from stakeholders related to the implementation of local subject learning in primary schools such as education/education service practitioners, principals, communities/school committees, teachers, and students. Determination of school as a respondent in preliminary research on stakeholder recommendations by considering the representation of each school so that it is chosen based on advanced, medium, and ordinary school practices.

\section{Data collecting technique}

Data collection in this study was carried out by interviews, observation, documentation, and questionnaires. Interviews were conducted to find out the community's response to the preservation of Sasak Alus language by giving questions "Does Sasak Alus language need to be preserved and taught through local subject learning?" These questions were given directly and also through telephone communication channels to several people in the Sasak community. Observations and documentation were carried out to determine the direct conditions for learning the local subject of Sasak Alus language at school. Questionnaires are used for learning needs analysis and validation of learning resources.

\section{Data analysis technique}

Qualitative data were analyzed by triangulation method and source techniques which included data collection, data reduction, data presentation, and conclusion. While data obtained from questionnaires were analyzed by descriptive statistics in the form of percentages (Creswell, 2012).

\section{DISCUSSION / ANALYSIS}

\section{Analysis of the needs of Sasak Alus language learning according to students}

The analysis of the need to learn Sasak Alus language was done by giving questionnaires to language learning needs to students adapted from Jack C. Richards 2001. The following are summarized the results of the preliminary research questionnaire in table form.

Table 1: Results of Needs Analysis of Learning Sasak Alus language

\begin{tabular}{lllll}
\hline \multirow{2}{*}{ No. } & Description & Percentage of answers (\%) \\
\cline { 3 - 5 } & & Very useful & $\begin{array}{l}\text { Useful } \\
\text { Not } \\
\text { useful }\end{array}$ \\
\hline A-1. & Sasak Alus language useful when buying things in a shop & 68,75 & 25,00 & 6,25 \\
\hline A-2 & Sasak Alus language is useful when buying goods on the market & 71,88 & 21,88 & 6,25 \\
\hline A-3 & $\begin{array}{l}\text { Sasak Alus language is useful to use when communicating with older } \\
\text { people }\end{array}$ & 90,63 & 9,38 & 0,00 \\
\hline A-4 & $\begin{array}{l}\text { Sasak Alus language useful to use when buying food in the school } \\
\text { cafeteria }\end{array}$ & 81,25 & 15,62 & 3,13 \\
\hline A-5 & Sasak Alus language is useful to use when using public transportation & 62,50 & 34,38 & 3,13 \\
\hline A-6 & Sasak Alus language useful to use when asking for directions or 90,63 & 9,38 & 0,00 \\
\hline
\end{tabular}




\begin{tabular}{lllll}
\hline \multicolumn{2}{l}{ something you want to know } & & \\
\hline A-7 & $\begin{array}{l}\text { Sasak Alus language useful to use when communicating with teachers } \\
\text { at school }\end{array}$ & 93,75 & 6,25 & 0,00 \\
\hline A-8 & Sasak Alus language useful to use when chatting with friends & 71,88 & 21,88 & 6,25 \\
\hline A-9 & Sasak Alus language useful to use when chatting with family at home & 84,37 & 15,63 & 0,00 \\
\hline A-10 & Sasak Alus language useful to use when receiving a call & 71,88 & 25,00 & 3,13 \\
\hline A-11 & Sasak Alus language useful to use when calling friends & 78,13 & 15,63 & 6,25 \\
\hline A-12 & $\begin{array}{l}\text { Sasak Alus language useful to use when communicating in the place of } \\
\text { recitation, playing, and other public places }\end{array}$ & 87,50 & 12,50 & 0,00 \\
\hline A-13 & Sasak Alus language useful to use when listening to folk songs & 71,88 & 21,88 & 6,25 \\
\hline A-14 & $\begin{array}{l}\text { Sasak Alus language useful to use when watching local cultural arts } \\
\text { performances }\end{array}$ & 56,25 & 40,63 & 3,13 \\
\hline A-15 & Sasak Alus language useful to use when chatting in a friend's house & 56,25 & 40,63 & 3,13 \\
\hline A-16 & $\begin{array}{l}\text { Sasak Alus language useful to use when conversing in the mosque were } \\
\text { to recite }\end{array}$ & 75,00 & 18,75 & 6,25 \\
\hline
\end{tabular}

Based on the results of the needs analysis questionnaire mentioned above, it can be concluded that the Sasak Alus language is useful to learn. From a number of questions given, in part B students were asked to choose 5 (five) places among the 16 places to use the Sasak Alus language they considered most important. Through questions at this point, it is known that the five important places to use Sasak Alus language are; (1) communicating with older people, (2) asking directions or asking questions, (3) communicating with teachers in schools, (4) conversing with family, (5) communicating at the place of recitation, playing, and other public places .

In addition to being asked about the location of places of use of Sasak Alus language, in section C it was asked about the ability of Sasak Alus language for students. From the answers of 32 students, it was known that 30 students did not know the Sasak Alus language at all. While 2 students know a few words; not able to use in conversation; and have not been able to answer questions. Based on the results of the needs analysis, it can be concluded that students cannot yet speak Sasak Alus language.

\section{According to the teachers}

Based on the results of interviews with local subject teachers, it is known that Sasak Alus language is important to be taught to students as self-identity to be a Sasak person. Furthermore, it was said that, based on the experience of interacting in daily life at school, students did not understand if the teacher interacted using Sasak language. For example, students do not understand the meaning of words selae (twenty-five), skeet (fifty), karobelah (one hundred and fifty), and several other calculations in Sasak Alus language. This shows that students do not understand their own language if it is not seriously taught, the Sasak Alus language will be extinct with the times.

\section{According to the principal}

The results of interviews with the Principal showed matching answers with local subject teachers about determining the material from local subject lessons. It was explained that local subject learning is a subject that is fully submitted to the school, the school can teach computers, English, dance, arts, crafts, or regional languages as local subject learning material. The principal agreed with the local subject teacher, that Sasak Alus language needed to be taught. So that the learning process can run better, learning materials are needed that are in accordance with the level of students' abilities.

According to the principal, the main purpose of Sasak Alus language learning is to shape the attitude of politeness in students when interacting with teachers, parents, community leaders or with people who are deemed necessary to be respected and valued. The polite and polite attitude shown through this language is important for students because students who have polite and polite attitude in language will be more easily accepted in community life. Moreover, in the life of the Sasak community, which is still very thick with kinship culture, it is very concerned about politeness in language, and even politeness in language is not uncommon as a benchmark for a person's high and low moral level.

\section{Development and validation of learning resources}

Based on the results of the needs analysis then it was developed a draft of learning resource products. The draft of the results of the development after being compiled was then validated by the experts of Sasak Alus language, learning media experts, and learning design experts. The following are the results of the expert's review.

\section{Validation results by the expert}

After the draft learning resource was completed, it was then validated by the material expert. The following data on the results of material expert validation on the learning resources developed are presented in the following table form. 
Table2: Results of Validation of Material Experts

\begin{tabular}{lll}
\hline Aspect & Indicator & Score \\
\hline \multirow{4}{*}{ Material } & Conformity of material with $S K$ and $K D$ & 87,5 \\
\cline { 2 - 3 } & Material description & 82,9 \\
\cline { 2 - 3 } & Linguistics & 83,3 \\
\cline { 2 - 3 } & Average & 84,5 \\
\hline
\end{tabular}

Table 3: Results of Validation of Learning Media Experts

\begin{tabular}{lll}
\hline Aspect & Indicator & Score \\
\hline \multirow{4}{*}{ Media } & Easy to use & 77,5 \\
\cline { 2 - 3 } & Font size, font type, and space & 75,0 \\
\cline { 2 - 3 } & Display & 79,1 \\
\cline { 2 - 3 } & Average & 77,2 \\
\hline
\end{tabular}

Table 4: Results of Expert Validation of Learning Design

\begin{tabular}{lll}
\hline Aspect & Indicator & Score \\
\hline & Clarity of learner goals & 84,3 \\
\cline { 2 - 3 } Design instructionales arning resources are suitable for a variety of learning and teaching styles & 80,0 \\
\cline { 2 - 3 } & Material presentation techniques & 81,2 \\
\cline { 2 - 3 } & Availability of evaluation tools & 87,5 \\
\cline { 2 - 3 } & Average & 83,2 \\
\hline
\end{tabular}

The average value of the results of the assessment of the three experts is 81.63 . This value, when converted into the conversion table, is in the usable category. From these values, it can be concluded that the learning resources developed can be used as a source of learning the local subject of Sasak Alus language.

\section{Evaluation by learners}

After the learning resources developed were validated by experts, then continued with conducting trials to students conducted through individual trials, small group trials, and field trials. The following is summarized the results of the assessment of the trial.

Table 5: Test Results by Students

\begin{tabular}{lllll}
\hline \multirow{2}{*}{ No. } & \multirow{2}{*}{ Aspect } & Results & & \\
\cline { 3 - 5 } & & One to One & Small-Group & Field Trial \\
\hline 1 & Display & 80,5 & 84,2 & 85,1 \\
\hline 2 & Material Presentation & 80,1 & 85,0 & 84,8 \\
\hline 3 & Benefits aspects & 81,9 & 87,0 & 87,5 \\
\hline 4 & Average & 80,8 & 85,4 & 85,8 \\
\hline
\end{tabular}

Based on the table above it is known that from each stage of the test (individual trials, small group trials, and field trials) obtained an average value indicating the learning resources developed are in the category of feasible use. Thus it can be concluded that based on the results of the trials conducted, it can be concluded that the learning resources developed are feasible to use.

\section{Implementation}

At the implementation stage, the effectiveness of learning resources was developed by involving 30 students. This effectiveness test was carried out at the time of the field trial, namely by giving the pre-test and post-test to the students. Based on a significant level of 5\% and $(\mathrm{df}=\mathrm{N}-1) 30-1=29$, the calculation of the value of " $\mathrm{t}$ " is $=14.69$. By comparing the magnitude of the $\mathrm{t}$-count obtained by the magnitude of $\mathrm{t}$-table, it can be seen that the $\mathrm{t}$-count is greater than t-label, which is $1,699<14,690$. Based on the results of the calculation, it can be concluded that there are significant differences in learning outcomes between before and after the use of learning resources as a result of development. Looking at the average or meant post-test which is greater than the average value of the pre-test results, it is known that the package of learning resources developed effectively to improve student learning outcomes. This means that learning the local subject of Sasak Alus language using learning resources developed is more effective than learning the local subject with regular learning that does not use learning resource packages from development results.

Based on the results of the effectiveness test above, it is known that the use of learning resources from the results of development affects the improvement of student learning outcomes. The results of this study are in line with the results of the research of Nugroho and Tri (Nugroho and Tri, 2015) which show that there is an influence of the use of learning resources on the process and learning outcomes of Natural Sciences in fifth-grade students in Rejowinangon of Elementary School 1 Yogyakarta. The research results also show that the application of short film media as a learning resource can 
have a significant influence on student learning outcomes. This is in line with the opinion (Karampiperis \& De Sampson, 2005) ; (Hill \& Hannafin, 2001) who says that the use of learning resources aims to improve the quality of the learning process and the variety of ways people learn and teach.

Learning from various bases of various sources (resource-based learning) leads to independent learning models (independent study), open learning and distance learning. Learning based on various sources as a concept of strategies and methods designed, developed, and applied to a subject matter to improve the activation of learning to achieve learning goals (Ryan et al., 2012). This learning model encourages students to learn actively and creatively according to their own style and abilities. This is in line with Sitepu (2014) who argues that learning and learning based on various sources is essentially a learning process that uses various sources to enable each learner to get the opportunity to learn according to his own style and speed of learning.

\section{CONCLUSION}

The development of learning resources begins with conducting preliminary research and needs analysis, then proceeding to develop the initial draft model, validating learning resources by material experts, media experts, learning design experts, individual trials, and small group trials, and field trials.

The use of learning resources in the learning process is intended to increase interaction and communication between all the components involved in the learning process. Interaction and communication that occur are directed at the learning objectives that have been set. Based on the implementation of the effectiveness of learning resources developed, it is proven that there are significant differences in learning outcomes before using learning resources as a result of development with student learning outcomes after learning resources are used as a result of development. This means that the use of development products is more effective than regular learning that does not use learning resources as a result of development.

\section{REFERENCES}

1. Amry, A. B. (2014). The Impact of Whatsapp Mobile Social Learning on the Achievement and Attitudes of Female Students Compared with Face to Face Learning In the Classroom. European Scientific Journal , 10 (22), 116-136.

2. Andrian, D., Kartowagiran, B., \& Hadi, S. (2018). The Instrument Development to Evaluate Local Curriculum in Indonesia. International Journal of Instruction , 11 (4), 921-934. https://doi.org/10.12973/iji.2018.11458a

3. Bjork, C. (2004). Decentralisation In Education, Institutional Culture And Teacher Autonomy In Indonesia. Netherlands: Kluwer Academic Publishers. https://doi.org/10.1007/s11159-004-2622-6

4. Bruff, D., Douglas F., Katherine M., and Blaine S., (2013). Wrapping a MOOC: Student perceptions of an experiment in blended learning. MERLOT Journal of Online Learningand Teaching, 9 (2), 187-199.

5. Burdina, G., M., Irina E., K., and Liliya G. N., (2019). Distance Learning in Elementary School Classrooms: An Emerging Framework for Contemporary Practice. International Journal of Instruction, 12 (1), 1-16. https://doi.org/10.29333/iji.2019.1211a

6. Chen, C.-C., \& Huang, T. C. (2012). Learning in a u-Museum: Developing a context-aware ubiquitous learning environment. Computers \& Education, 59 (3), 873-883. https://doi.org/10.1016/j.compedu.2012.04.003

7. Creswell (2012). Educational Research: Planning, Conducting, and Evaluating Quantitative and Qualitative Research Planning, Conducting, and Evaluating Quantitative and Qualitative Research. Fourth edition. Boston: Pearson Education, Inc.

8. Department of Education (2008). Evaluation and Selection of Learning Resources: A Guide, (Prince Edward Island, Canada)Evaluation and Selection of Learning Resources: A Guide, (Prince Edward Island, Canada). Canada: www.gov.pe.ca/photos/original/ed_ESLR_08.pdf.

9. Dorrell, J. (1993). Resources Based learning: Using Open and Flexible Learning Resources for Continuous Development. New York: McGraw-Hill Book Company.

10. Furió, D., Juan, M.-C., Seguí, I., and Vivó, R. (2015). Mobile learning vs traditional classroom lessons: a comparative study. Journal of Computer Assisted Learning, 31 (3). https://doi.org/10.1111/jcal.12071

11. Ganapathy, M., Vivien C., P., W., Vighnarajah, and Chong J.,J, (2015). Teachers' Perceptions of Creating, Sharing and Using Open Education Resources (OERs) in Universiti Sains Malaysia (USM). International Journal of e-Education, e-Business, e-Management and e-Learning, 5, (2), 62-72. https://doi.org/10.17706/ijeeee.2015.5.2.62-72

12. Hadjerrouit, S. (2010). Developing Web-Based Learning Resources in. Interdisciplinary Journal of E-Learning and Learning Objects, (6), 115-135. https://doi.org/10.28945/1172

13. Hafner, C. A., \& Miller, L. (2011). Fostering learner autonomy in english for science: A collaborative digital video project in a Technological Learning Environment. Language Learning \& Technolog, 15 (3), 68-86.

14. Hidayat. (2010). Bahasa Sasak Halus dan Prilaku Sosial Masyarakat Penuturnya. Seminar Nasional Pemertahanan Bahasa Nusantara, (pp. 249-257). Semarang: Magister Linguistik PPs UNDIP Semarang.

15. Hill, J. R., \& Hannafin, M. J. (2001). Teaching and Learning in Digital Environments: The Resurgence of Resource-Based Learning. ETR\&D, 49 (3), 37-52. https://doi.org/10.1007/BF02504914 
16. Hsu, T.-C., \& Hwang, G. J. (2017). Effects of a Structured Resource-based Web Issue-Quest Approach on Students'Learning Performances in Computer Programming Courses. Journal of Educational Technology \& Society, 20 (3), 82-94.

17. Januszewski, A., \& Molenda, M. (2008). Educational Technology: A Definition with Complementary. New York: Lawrence Erlbaum Associates.

18. Karampiperis, P., \& DeSampson, D. G. (2005). Adaptive Learning Resources Sequencing in Educational Hypermedia Systems. Educational Technology \& Society, 8 (4), 128-147.

19. Katz, H. (2003). The Media Handbook: A Complete Guide to Advertising Media Selection, Planning, Research, and Buying. New Jersey: Lawrence Erlbaum Associates Publishers.

20. Kumalasari, G. W. (2019). Local Government Policy Model Of Indonesia Rattan Handicraft Creative Industry In Trangsan Village. Humanities \& Social Sciences Reviews , 87-9187-91. https://doi.org/10.18510/hssr.2019.7313

21. Manca, S., \& Ranieri, M. (2013). Is it a Tool Suitable for Learning? A critical review of the literature on Facebook as a Technology-Enhanced Learning Environment..Journal of Computer Assisted Learning, 29, (6) 487504. https://doi.org/10.1111/jcal.12007

22. McPherson, M., \& Nunes, M. B. (2014). The Role of Tutors as an Integral Part of Online Learning Support. European Journal of Open, Distance and E-Learning, http://eprints.whiterose.ac.uk/999/1/Maggie_MsP.html.

23. Miarso, Y. (2005). Menyemai Benih Teknologi Pendidikan. Jakarta: Pestekom.

24. Miles B., M., A. Michael, H., Johnny S., (2014). Qualitative Data Analysis: a Methods Sourcebook. Third edition. Arizona : Arizona State University.

25. Mohammadi, F., A. Abrizah, and Nazari. (2015). Is the Information Fit For Use? Exploring Teachers Perceived Information Quality Indicators for Farsi Web-based Learning Resources. Malaysian Journal of Library \& Information Science, 20 (1), 99-100.

26. Mubah, A. S. (2011). Strategi Meningkatkan Daya Tahan Budaya Lokal dalam Menghadapi Arus Globalisasi. Journal Universitas Airlangga, 302-308.

27. Mugni. (2012). Pemertahanan Bahasa Sasak Pada Keluarga Bangsawan Lombok. Jakarta Indonesia: Diseratasi, Program Pascasarjana Universitas Negeri Jakarta.

28. Muharria, Syafruddin Y., and Sri K. (2016). Pengaruh Penerapan Media Film Pendek Sebagai Sumber Pembelajaran Sejarah Terhadap Hasil Belajar Siswa di Kelas X Matematika Ilmu Alam Sekolah Menengah Atas Negeri 13 Palembang,. Jurnal Criksetra , 5 (9), 48-57.

29. Nugroho and Tri. (2015). Pengaruh Media Video Pembelajaran Terhadap Keterampilan Proses dan Hasil Belajar IPA di Kelas V SD Negeri Rejowinangun 1 Yogyakarta,. Jurnal Pendidikan Guru Sekolah Dasa , 6 (4), 1-15.

30. Poon, J. (2013). Blended Learning: An Institutional Approach for Enhancing Students' Learning Experiences. MERLOT Journal of Online Learning and Teaching , 9 (2), 271-288.

31. Prastiwi. (2013). Transmitting Local Cultural Knowledge through English as Foreign Language (EFL) Learning as a Means of Fostering "Unity in Diversity". Academic Journal of Interdisciplinary Studies , 2 (3), 507-513. https://doi.org/10.5901/ajis.2013.v2n3p507

32. Richards. (2003). Curriculum Development in Language Teaching. New York: Cambridge University Press.

33. Ryan,S. Bernard S., Howard F., and Daxa P., (2012). The Virtual University: The Internet and Resource-based Learning. Londong: Routledge. https://doi.org/10.4324/9781315042022

34. Scanlon E., McAndrew, P., O'Shea, T. (2015). Designing for Educational Technology to Enhance the Experience of Learners in Distance Education: How Open Educational Resources, Learning Design and Moocs Are Influencing Learning. Journal of Interactive Media in Education , 1 (6), 1-9. https://doi.org/10.5334/jime.al

35. Seels, B. B., \& Richey, R. C. (1994). Teknologi Pembelajaran : Definisi dan Kawasannya (terjemahan). Jakarta: PPs UNJ.

36. Sitepu, B. P. (2014). Pengembangan Sumber Belajar. Jakarta: PT RajaGrafindo Persada.

37. Smellie., D. C., \& Kemp, J. E. (1989). Planning, Producing, and Using Instructional Media. New Yor: Harper \& Row Publishers.

38. Sumiati, D. (2017). Intercultural Communication Based on Local Wisdom That Made the People of Bali Reject Sharia Tourism. Asian Journal of Media and Communication, 1 (2), 137-146.

39. Supriadi. (2015). Pemanfaatan Sumber Belajar Dalam Proses Pembelajaran. Lantanida Journal, 3 ( 2), 127-139. https://doi.org/10.22373/li.v3i2.1654

40. Suryadi, E., \& Kusnendi. (2016). The Influence of Local Wisdom on the Actualisation of Educative, Scientific and Religious Behaviour on an Academic Environment in a University. American Journal of Applied Sciences, 13 (4), 467-476. https://doi.org/10.3844/ajassp.2016.467.476

41. Wong, L.-H. (2012). A learner-centric view of mobile seamless learning. British Journal of Educational Technology, 43 (1), 19-23. https://doi.org/10.1111/j.1467-8535.2011.01245.x

42. Yunus, R. (2013). Transformasi Nilai-nilai Budya Lokal Sebagai Upaya Pembangunan Karakter Bangsa. Jurnal Penelitian Pendidikan, 13 (1), 67-79. 